\title{
Pengembangan Hybrid Tepung Ubi Jalar Kaya Antioksidan
}

\author{
Sefanadia Putri \\ Jurusan Gizi, Politeknik Kesehatan Tanjung Karang, Indonesia \\ Email: sefanadia@ poltekkes-tjk.ac.id
}

\begin{abstract}
Development of Hybrid Sweet Potato Flour High in Antioxidant. Sweet potato is one type of tubers found in Indonesia. Hybrid of sweet potato flour is obtained from the modification of the processing by fermentation using lactic acid bacteria. The purpose of this study was to determine the nutritional and antioxidant content of various types of hybrid sweet potato flour. This research is an experimental laboratory with a true-experiment design. The experiment was arranged in a complete randomized block design (RCB) with three replications. The treatments are 6 types of sweet potatoes which include purple sweet potato Var.Antin 1, purple sweet potato val.local, white sweet potato, orange sweet potato, Japanese purple sweet potato Var.Ayamurasaki and cilembu sweet potato. The study included the fermentation process using lactic acid bacteria (Acetobacter xylinum) addition concentration of 5\%, siege, analysis of nutrient content (water, ash, protein, fat, fiber and carbohydrates) and antioxidant activity of various types of hybrid sweet potato flour. The results showed that various types of hybrid sweet potato flour significantly affect the nutritional content which includes water content, ash content, fat content, protein content, fiber content and total carbohydrate. The result of antioxidant activity in various types of hybrid sweet potato flour after fermentation treatment in a concentration of 5\% Acetobacter xylinum ranged from 29,383-53.7929\%. The lowest value obtained at cilembu hybrid sweet potato flour and the highest value was obtained from the Japanese hybrid sweet potato flour var.Ayamurasaki.
\end{abstract}

Keywords: Antioksidan activity, Hybrid of sweet potato flour, Nutritional

\begin{abstract}
Abstrak: Pengembangan Hybrid Tepung Ubi jalar Kaya Antioksidan. Ubi jalar merupakan salah satu jenis ubi yang banyak ditemui di Indonesia. Hybrid tepung ubi jalar didapatkan dari modifikasi proses pengolahan dengan cara fermentasi yang memanfaatkan bakteri asam laktat. Tujuan dari penelitian ini untuk mengetahui kandungan gizi dan antioksidan berbagai jenis hybrid tepung ubi jalar. Penelitian ini merupakan penelitian eksperimental laboratorium dengan desain true-experiment. Percobaan disusun dalam rancangan acak kelompok lengkap (RAKL) dengan tiga kali ulangan. Perlakuan yakni 6 jenis ubi jalar yang meliputi ubi ungu Var.Antin 1, ubi ungu val.lokal, ubi jalar putih, ubi jalar orange, ubi jalar ungu jepang Var.Ayamurasaki dan ubi cilembu. Penelitian meliputi proses fermentasi menggunakan bakteri asam laktat (Acetobacter xylinum) konsentrasi penambahan sebesar 5\%, penepungan, analisa kandungan gizi (air, abu, protein, lemak, serat dan karbohidrat) serta aktivitas antioksidan berbagai jenis hybrid tepung ubi jalar. Hasil penelitian menunjukkan bahwa berbagai jenis hybrid tepung ubi jalar berpengaruh secara nyata terhadap kandungan gizi yang meliputi kadar air, kadar abu, kadar lemak, kadar protein, kadar serat serta total karbohidrat. Aktivitas antioksidan yang dihasilkan pada berbagai jenis hybrid tepung ubi jalar setelah mengalami perlakuan fermentasi dalam larutan Acetobacter xylinum konsentrasi 5\% berkisar antara 29.383-53.7929\%. Nilai terendah didapat pada hybrid tepung ubi jalar cilembu dan nilai tertinggi didapat pada hybrid tepung ubi ungu jepang var.Ayamurasaki.
\end{abstract}

Kata kunci: Aktivitas antioksidan, Hybrid tepung ubi jalar, Kandungan gizi

\section{PENDAHULUAN}

Ubi jalar merupakan salah satu jenis ubi yang banyak ditemui di Indonesia Berdasarkan warna umbinya, ubi jalar terdiri dari ubi jalar putih, ubi jalar kuning, ubi jalar jingga, dan ubi jalar ungu. Pada ubi jalar, pangan fungsional diperoleh dari betakaroten dan antosianin, senyawa fenol, serat pangan, dan nilai indeks glikemiknya (Glycemic Index) (Ginting, E. dkk., 2006). Seiring dengan meningkatnya kesadaran masyarakat akan pentingnya hidup sehat, maka tuntutan konsumen terhadap bahan pangan juga kian bergeser. Bahan pangan yang kini mulai 
banyak diminati konsumen bukan saja yang mempunyai penampakan dan citarasa yang menarik, tetapi juga harus memiliki fungsi fisiologis tertentu bagi tubuh.

Keberadaan senyawa antioksidan pada ubi jalar menjadikan jenis bahan pangan ini sangat menarik untuk diolah menjadi makanan yang mempunyai nilai fungsional. Konsumsi makanan yang mengandung antioksidan dapat menghambat timbulnya penyakit degeneratif melalui penghambatan reaksi oksidasi dengan mengikat radikal bebas. Peningkatan produk dari ubi jalar dapat dilakukan menjadi produk setengah jadi melalui hybrid tepung ubi jalar yang selanjutnya dapat digunakan sebagai bahan substitusi tepung terigu pada produk donat, brownies, roti tawar, mie, biskuit, muffin dan lainnya.

Hybrid tepung ubi jalar didapatkan dari modifikasi proses pengolahan dengan cara fermentasi yang memanfaatkan bakteri asam laktat (BAL) seperti pada ubi kayu yang disebut MOCAF (Modified Cassava Flour). Subagio (2008), melaporkan bahwa pada saat fermentasi, ubi kayu mengalami perubahan sifat tepung yang dihasilkan berupa naiknya viskositas, kemampuan gelasi, daya rehidrasi, kemudahan melarut, dan aroma serta rasa yang disukai konsumen. Proses fermentasi akan mempengaruhi kandungan serat kasar, kadar abu dan lemak. Serat kasar terdiri dari senyawa selulosa, hemi-selulosa dan lignin yang tidak dapat dicerna oleh manusia (Muchtadi, 2001). Modifikasi pada tepung ubi kayu telah dilakukan dan dimanfaatkan sebagai bahan baku industri makanan.

Salah satu produk diversifikasi pangan setengah jadi ubi jalar yakni tepung ubi jalar termodifikasi dengan menggunakan metode fermentasi bakteri asam laktat yang berupa Acetobacter xylinum, sehingga dapat dimanfaatkan dengan berbagai macam hasil olahan berbasis tepung terigu. Suryati (2014) melaporkan bahwa tepung ubi jalar tergelatinisasi sebagian dapat mempertahankan kapasitas antioksidan. Susetyo; dkk (2016) melaporkan bahwa tepung modifikasi ubi jalar yang ditambah angkak dengan dosis $0 \% \mathrm{w} / \mathrm{w}$ (sebagai kontrol), 5\% w/w, 10\% w/w, 15\% w/w dan $20 \%$ w/w didapat hasil bahwa penambahan inokulum angkak dengan dosis 5\% dapat meningkatkan kandungan protein, lemak, derajat asam, antioksidan serta menurunkan karbohidrat, serat dan kadar abu. Oleh karena itu pada penelitian ini akan dikaji pengembangan hybrid berbagai jenis tepung ubi jalar dengan konsentrasi pemberian BAL sebesar 5\% w/w sehingga didapatkan kandungan gizi tepung ubi jalar temodifikasi yang meliputi kandungan air, abu, protein, lemak, serat, karbohidrat serta aktivitas antioksidan. Tujuan penelitian ini adalah untuk mengetahui pengaruh berbagai jenis hybrid tepung ubi jalar terhadap kandungan gizi yang meliputi kadar air, kadar abu, kadar lemak, kadar protein, kadar serat serta kadar karbohidrat serta untuk mengetahui aktivitas antioksidan berbagai jenis hybrid tepung ubi jalar.

\section{METODE}

Penelitian ini merupakan penelitian eksperimental laboratorium dengan desain trueexperiment. Percobaan disusun dalam rancangan acak kelompok lengkap (RAKL) dengan tiga ulangan. Perlakuan yakni 6 jenis ubi jalar yang meliputi ubi jalar ungu Var. antin 1, ubi jalar ungu Var.Ayamurasaki, ubi jalar putih, ubi jalar orange, ubi jalar jepang dan ubi jalar cilembu. Penelitian meliputi proses fermentasi menggunakan bakteri asam laktat (Acetobacter xylinum) konsentrasi penambahan sebesar 5\%, penepungan, kemudian dilanjutkan dengan analisa kandungan gizi yang meliputi: air (AOAC, 1995), abu (AOAC, 1995), protein (Metode Gunning (Sudarmadji, 2003)), lemak (metode Sokhlet (AOAC, 1995)), serat (Metode Gravimetri (Sudarmadji, 2003)) dan karbohidrat metode By difference) serta aktivitas antioksidan metode Amin dan Lee (2005) untuk berbagai jenis hybrid tepung ubi jalar. Penelitian dilaksanakan pada bulan Juli-Oktober 2017. Objek pada penelitian ini adalah berbagai jenis ubi jalar yang diolah menjadi hybrid tepung ubi jalar menggunakan proses fermentasi bakteri asam laktat (Acetobacter xylinum). Berbagai jenis ubi jalar didapat dari pasar tradisional Bandar Lampung sedangkan bakteri asam laktat (Acetobacter xylinum) didapat dari home industri binaan Politeknik Negeri Lampung.

\section{Prosedur Kerja Tepung Hybrid Ubi Jalar}

Sebelum berbagai jenis ubi jalar diproses, dilakukan sortasi terlebih dahulu untuk memisahkan ubi jalar yang rusak dan tidak memenuhi standar mutu, kemudian dilakukan penimbangan agar dapat diketahui berat kotor dan berat bersih sehingga total produk dapat dianalisis dan dapat dihitung tingkat kegagalannya. Ubi jalar yang telah dikupas kemudian ditampung dalam ember yang berisi air. Setelah dikupas, ubi jalar dicuci menggunakan air bersih, kemudian dipotongpotong tipis-tipis berbentuk chips berukuran 
kurang lebih $0,2-0,3 \mathrm{~cm}$. Proses fermentasi chips ubi jalar dilakukan menggunakan ember yang berisi air, kemudian dilarutkan bakteri Acetobacter xylinum dengan konsentrasi 5\% dari volume chips dan air. Perendaman chips ubi jalar ungu diupayakan tenggelam oleh air. Fermentasi dilakukan selama 30 jam. Setelah proses fermentasi selesai, dilakukan pencucian kembali untuk menghilangkan sifat asam pada chips ubi jalar ungu hingga tidak berasa dan tidak berbau. Kemudian chips ditiriskan dengan menggunakan tampah dari anyaman bambu. Chips ubi jalar yang telah difermentasi ditiriskan dan dijemur dibawah sinar matahari dengan suhu panas normal atau menggunakan metode oven pada suhu $60{ }^{\circ} \mathrm{C}$ hingga mencapai kadar air $13 \%$ atau chips sudah mulai kering dan mudah dihancurkan. Proses penepungan dilakukan setelah chips ubi jalar ungu kering, selanjutnya dilakukan proses penepungan menggunakan food grinder. Pengayakan dilakukan untuk menghasilkan tepung yang halus. Pengayakan dilakukan secara manual menggunakan saringan dengan mesh 80.

Analisis data yang digunakan adalah analisis univariat, yaitu dengan menampilkan hasil penilaian berupa nilai rata-rata (mean) dari masing-masing variabel untuk mengetahui distribusi frekuensi dari tabel-tabel yang diamati sehingga dapat mengetahui karakteristik atau gambaran dari semua variabel, yaitu air, abu, protein, lemak, serat dan karbohidrat serta aktivitas antioksidan produk dengan menggunakan tampilan berupa tabel atau grafik. Kemudian analisis bivariat menggunakan uji analysis of variance (Anova). Namun jika data yang didapat tidak memenuhi syarat dari uji Anova maka analisis bivariat dilanjutkan dengan menggunakan uji Kruskalwalis. Apabila terdapat pengaruh analisis ragam maka dilanjutkan dengan uji lanjut Duncan Multiple Range Test (DMRT).

\section{HASIL}

\section{Kandungan Gizi Hybrid Tepung Ubi Jalar}

Hasil uji statistik didapat nilai $p$ untuk kadar air sebesar $=0,001$, sedangkan nilai $p$ untuk kadar abu, protein, lemak, serat dan karbohidrat sebesar 0,005. Hasil uji statistik menyatakan bahwa kandungan gizi yang meliputi kadar air, kadar abu, protein, lemak, serat dan karbohidrat berbagai jenis hybrid tepung jalar pada alpha 5\% terdapat perbedaan secara nyata. Kandungan gizi berbagai jenis hybrid tepung ubi jalar dapat dilihat pada Tabel 1 .

Tabel 1. Kandungan Gizi Berbagai Jenis Hybrid Tepung Ubi Jalar

\begin{tabular}{|c|c|c|c|c|c|c|}
\hline $\begin{array}{l}\text { Variabel (ubi } \\
\text { jalar) }\end{array}$ & $\begin{array}{c}\text { Kadar air } \\
(\%)\end{array}$ & $\begin{array}{c}\text { Kadar abu } \\
(\%)\end{array}$ & $\begin{array}{c}\text { Kadar } \\
\text { protein }(\%)\end{array}$ & $\begin{array}{c}\text { Kadar } \\
\operatorname{lemak}(\%)\end{array}$ & $\begin{array}{c}\text { Kadar } \\
\text { serat }(\%)\end{array}$ & $\begin{array}{c}\text { Kadar } \\
\text { karbohidrat } \\
(\%)\end{array}$ \\
\hline Orange $(\mathrm{O})$ & 4,577 (a) & $2,716(d)$ & $3,64 \quad(d)$ & 1,34 (c) & 8,399 (d) & $79,326(\mathrm{a})$ \\
\hline Jepang (J) & 4,595 (a) & 0,768 (b) & 2,377 (b) & 0,783 (b) & 4,163 (c) & $87,352(\mathrm{c})$ \\
\hline $\begin{array}{l}\text { ungu Var. } \\
\text { Ayamurasaki (U) }\end{array}$ & 4,588 (a) & 0,727 (b) & $3,582(d)$ & 0,314 (a) & 4,596 (c) & 86,191 (b) \\
\hline Putih (P) & 4,884 (a) & $1,342(\mathrm{c})$ & $3,041 \quad(\mathrm{c})$ & $0,41 \quad$ (a) & 2,812 (a) & $87,51(\mathrm{~cd})$ \\
\hline Cilembu (C) & $5,565(b)$ & $0,538(a)$ & 2,352 (b) & 0,961 (b) & 2,613 (a) & 87.97 (d) \\
\hline $\begin{array}{l}\text { ungu Var. antin } 1 \\
(\mathrm{PU})\end{array}$ & $4,536(a)$ & 1,347 (c) & 1,663 (a) & $0,991(b)$ & 3,457 (b) & $88,01(d)$ \\
\hline -value & 0,001 & 0,0005 & 0,0005 & 0,0005 & 0,0005 & 0,0005 \\
\hline
\end{tabular}

Hasil uji lanjut DMRT menunjukkan bahwa kadar air hybrid tepung ubi jalar sampel C (cilembu) nyata lebih tinggi dan berbeda nyata dengan hybrid tepung ubi jalar sampel O, J, U, P dan PU. Hasil uji lanjut DMRT menunjukkan bahwa kadar abu hybrid tepung ubi jalar sampel $\mathrm{O}$ (orange) nyata lebih tinggi dan berbeda nyata dengan hybrid tepung ubi jalar sampel P, PU, J, $\mathrm{U}$ dan $\mathrm{C}$ sedangkan hybrid tepung ubi jalar sampel $\mathrm{P}$ (putih) tidak berbeda nyata PU (ubi jalar ungu var. antin 1) serta hybrid tepung ubi jalar sampel $\mathrm{J}$ (Ubi ungu jepang var.Ayamurasaki) tidak berbeda nyata U (ubi jalar ungu Var. lokal).

Hasil uji lanjut DMRT menunjukkan bahwa kadar protein hybrid tepung ubi jalar sampel $\mathrm{O}$ (orange) nyata lebih tinggi dan berbeda nyata dengan hybrid tepung ubi jalar sampel $\mathrm{P}$, 
PU, J dan C sedangkan hybrid tepung ubi jalar sampel $\mathrm{O}$ (orange) tidak berbeda nyata dengan hybrid tepung ubi jalar sampel $\mathrm{U}$ (ubi jalar ungu Var.lokal) serta hybrid tepung ubi jalar sampel J (Ubi ungu jepang var.Ayamurasaki) tidak berbeda nyata $\mathrm{C}$ (cilembu).

Hasil uji lanjut DMRT menunjukkan bahwa kadar lemak hybrid tepung ubi jalar sampel $\mathrm{O}$ (orange) nyata lebih tinggi dan berbeda nyata dengan hybrid tepung ubi jalar sampel $\mathrm{P}$, PU, J, U dan C sedangkan hybrid tepung ubi jalar sampel PU (ubi jalar ungu Var. antin 1) tidak berbeda nyata dengan $\mathrm{C}$ (cilembu) dan $\mathrm{J}$ (Ubi ungu jepang var.Ayamurasaki) serta hybrid tepung ubi jalar sampel $\mathrm{U}$ (ubi jalar ungu Var.lokal) tidak berbeda nyata $\mathrm{P}$ (putih).

Hasil uji lanjut DMRT menunjukkan bahwa kadar serat hybrid tepung ubi jalar sampel $\mathrm{O}$ (orange) nyata lebih tinggi dan berbeda nyata dengan hybrid tepung ubi jalar sampel P, PU, J, $\mathrm{U}$ dan $\mathrm{C}$ sedangkan hybrid tepung ubi jalar sampel U (ubi jalar ungu Var.lokal) tidak berbeda nyata dengan $\mathrm{J}$ (Ubi ungu jepang var.Ayamurasaki) serta hybrid tepung ubi jalar sampel $\mathrm{P}$ (putih) tidak berbeda nyata $\mathrm{C}$
(Cilembu). Hasil uji lanjut DMRT menunjukkan bahwa total karbohidrat hybrid tepung ubi jalar sampel PU (ubi jalar ungu Var. antin 1) nyata lebih tinggi dan berbeda nyata dengan hybrid tepung ubi jalar sampel $\mathrm{U}, \mathrm{J}$ dan $\mathrm{O}$ namun tidak berbeda nyata dengan hybrid tepung ubi jalar sampel C dan P.

\section{Aktivitas Antioksidan}

Hasil uji statistik didapat nilai $p=0,0005$, bearti pada alpha 5\% dapat disimpulkan bahwa terdapat perbedaan secara nyata aktivitas antioksidan berbagai hybrid tepung ubi jalar. Aktivitas antioksidan berbagai jenis hybrid tepung ubi jalar dapat dilihat pada Tabel 2. Hasil uji lanjut DMRT menunjukkan bahwa aktivitas antioksidan hybrid tepung ubi jalar sampel J (Ubi ungu jepang var.Ayamurasaki) nyata lebih tinggi dan berbeda nyata dengan hybrid tepung ubi jalar sampel P, PU, J, U , O dan C sedangkan hybrid tepung ubi jalar sampel PU (ubi jalar ungu Var. antin 1) tidak berbeda nyata dengan $\mathrm{O}$ (orange).

Tabel 2. Aktivitas antioksidan berbagai jenis hybrid tepung ubi jalar

\begin{tabular}{lrrrr}
\hline \multicolumn{1}{c}{ Variabel } & Mean & \multicolumn{1}{c}{ SD } & 95\% CI & p-value \\
\hline Aktivitas antioksidan & & & & \\
Orange (O) & 37.8187 (c) & 1.1701 & $34.91-40.725$ & \\
Jepang (J) & 53.7929 (e) & 1.6981 & $49.574-58.011$ & \\
ungu Var. Ayamurasaki (U) & 43.3270 (d) & 0.78 & $41.387-45.267$ & 0,0005 \\
Putih (P) & 31.665 (b) & 0.354 & $30.784-32.545$ & \\
Cilembu (C) & 29.383 (a) & 0.755 & $27.5-31.2599$ & \\
ungu Var. antin 1 (PU) & 38.2987 (c) & 1.257 & $35.175-41.422$ & \\
Keterangan: Huruf yang berbeda ke arah kolom menunjukkan berbeda nyata menurut uji DMRT pada taraf 5 \%.
\end{tabular}

\section{PEMBAHASAN}

\section{Kandungan Gizi Hybrid Tepung Ubi Jalar}

Pengolahan berbagai jenis ubi jalar menjadi bentuk berbagai jenis hybrid tepung ubi jalar merupakan salah satu cara yang dapat dilakukan untuk mempermudah penyimpanan dan pengawetan ubi jalar. Pengolahan ubi jalar menjadi bentuk hybrid tepung ubi jalar juga dapat memperpanjang umur simpan bahan dan digunakan sebagai bahan baku industri pangan maupun non- pangan (Murtiningsih dan Suyanti, 2011). Pengujian terhadap keenam produk tersebut bertujuan untuk melihat dan membandingkan seberapa banyak sumbangan kandungan gizi yang diberikan oleh berbagai jenis hybrid tepung ubi jalar menggunakan metode fermentasi BAL yakni Acetobacter xylinum dengan konsentrasi sebesar $5 \%$.

\section{Kadar Air}

Berdasarkan hasil penelitian, kadar air yang dihasilkan pada berbagai jenis hybrid tepung ubi jalar setelah mengalami perlakuan fermentasi dalam larutan Acetobacter xylinum konsentrasi 5\% berkisar antara 4,536-5,565\%. Beberapa hasil penelitian di Indonesia menunjukkan bahwa tepung ubi jalar yang dihasilkan memiliki kadar air rata-rata mencapai $7,81 \%$ dengan kisaran antara 6,77\%-10,99\%.

Hasil pengukuran kadar air menunjukkan bahwa hybrid tepung ubi jalar ungu varietas antin 1 (PU) memiliki nilai yang paling rendah dibandingkan dengan hybrid tepung ubi jalar jenis lainnya dan hybrid tepung ubi jalar jenis cilembu (C) memiliki nilai yang paling tinggi dibandingkan dengan hybrid tepung ubi jalar jenis lainnya. Hasil penelitian Julita (2012) menyatakan bahwa kadar air tepung ubi cilembu 
sebesar $6,11 \%$ dengan rendemen sebesar $15,94 \%$, sedangkan hybrid tepung ubi cilembu memiliki kadar air sebesar $5,565 \%$ dengan rendemen sebesar 21,67\%. Menurut Setiavani (2010), proses fermentasi menyebabkan selulosa yang terurai semakin banyak dan semakin lunak struktur ubi jalar sehingga semakin mudah proses pengilingan dan menghasilkan rendemen tepung semakin meningkat.

Menurut Sofyan (2005), bahwa pada fermentasi \pm 24 jam terjadi penguraian senyawa-senyawa organik oleh adanya aktivitas enzim yang menghasilkan senyawa sederhana juga hasil lain dari proses metabolisme yaitu $\mathrm{H}_{2} \mathrm{O}$, energi dalam bentuk panas dan bahanbahan lainnya. Dengan terbentuknya panas selama proses fermentasi maka suhu bahan akan meningkat dan air yang dihasilkan selama proses fermentasi akan menguap sehingga terjadi penurunan kadar air. Sehingga diduga dengan adanya perlakuann fermentasi maka panas sebagai hasil metabolisme meningkat dan menyebabkan kadar air menurun.

Kadar air yang rendah berperan penting dalam menjaga keawetan suatu bahan pangan. Kadar air umumnya berbanding lurus dengan aktifitas air, yaitu semakin kecil kadar air, maka semakin kecil aktivitas air sehingga semakin awet bahan pangan tersebut. Aktivitas air yang rendah akan menghambat pertumbuhan mikroba pada bahan pangan sehingga bahan pangan menjadi lebih awet (Winarno, 1997). Rendahnya kadar air berbagai jenis hybrid tepung ubi jalar dalam penelitian ini diduga karena pada proses produksi setelah proses fermentasi selesai, dilanjutkan proses pengeringan dalam drying carbinet pada suhu $50^{\circ} \mathrm{C}$ selama 36 jam sehingga kadar air pada berbagai jenis hybrid tepung ubi jalar berkurang.

Hasil uji lanjut DMRT menunjukkan bahwa terdapat perbedaan secara nyata kadar air berbagai hybrid tepung ubi jalar. Perbedaan kadar air yang dihasilkan pada penelitian ini disebabkan karena perbedaan kadar air awal berbagai jenis ubi jalar yang digunakan dalam penelitian, sehingga mempengaruhi kadar air pada berbgai jenis hybrid tepung ubi jalar.

\section{Kadar Abu}

Berdasarkan hasil penelitian, kadar abu yang dihasilkan pada berbagai jenis hybrid tepung ubi jalar setelah mengalami perlakuan fermentasi dalam larutan Acetobacter xylinum konsentrasi $5 \%$ berkisar antara 0,538-2,716\%. Beberapa hasil penelitian di Indonesia menunjukkan bahwa tepung ubi jalar yang dihasilkan memiliki kadar abu rata-rata mencapai 4,17\% dengan kisaran antara 2,58\%-5,31\%.

Hasil pengukuran kadar abu menunjukkan bahwa hybrid tepung ubi jalar jenis cilembu (C) memiliki nilai yang paling rendah dibandingkan dengan hybrid tepung ubi jalar jenis lainnya. Hasil penelitian Julita (2012) menyatakan bahwa kadar abu tepung ubi cilembu sebesar 2,44\% lebih tinggi dibandingkan hybrid tepung ubi cilembu pada penelitian ini. Hybrid tepung ubi jalar jenis orange $(\mathrm{O})$ memiliki nilai yang paling tinggi dibandingkan dengan hybrid tepung ubi jalar jenis lainnya. Kadar abu tepung ubi jalar orange pada penelitian Aulia; dkk (2015) sebesar $3,46 \%$ lebih tinggi dibandingkan dengan kadar abu hybrid tepung ubi jalar orange pada penelitian ini. Kadar abu yang rendah kemungkinan disebabkan pada proses perendaman dengan larutan BAL pada konsentrasi 5\% menyebabkan sebagian mineral yang terdapat pada ubi terlarut bersama air rendaman dan terbuang bersama proses pencucian setelah perendaman. Menurut Bogasari (2010), kadar abu mempengaruhi warna produk (warna crumb pada roti, warna mie) dan tingkat kestabilan adonan. Semakin tinggi kadar abu semakin buruk kualitas tepung dan sebaliknya semakin rendah kadar abu semakin baik kualitas tepung.

Hasil uji lanjut DMRT menunjukkan bahwa terdapat perbedaan secara nyata kadar abu berbagai jenis hybrid tepung ubi jalar. Perbedaan kadar abu yang dihasilkan pada penelitian ini disebabkan karena perbedaan kadar abu awal berbagai jenis ubi jalar yang digunakan dalam penelitian, sehingga mempengaruhi kadar abu pada berbagai jenis hybrid tepung ubi jalar. Menurut Antarlina dan Utomo (1993) kadar abu tepung ubi jalar maksimal 2,13\%. Penelitian ini menunjukkan bahwa kadar abu dari berbagai jenis hybrid tepung ubi jalar yang diperoleh sudah memenuhi standar yang ditetapkan.

\section{Kadar Protein}

Berdasarkan hasil penelitian, kadar protein yang dihasilkan pada berbagai jenis hybrid tepung ubi jalar setelah mengalami perlakuan fermentasi dalam larutan Acetobacter xylinum konsentrasi 5\% berkisar antara 1,663-3,64\%. Beberapa hasil penelitian di Indonesia menunjukkan bahwa tepung ubi jalar yang dihasilkan memiliki kadar protein rata-rata mencapai 3,18\% dengan kisaran antara 2,114,46\%. Hal ini menunjukkan bahwa kadar protein dari berbagai jenis hybrid tepung ubi jalar yang 
diperoleh sesuai dengan kadar protein dari beberapa hasil penelitian di Indonesia.

Hasil pengukuran kadar protein menunjukkan bahwa hybrid tepung ubi jalar varietas antin 1 (PU) memiliki nilai yang paling rendah dibandingkan dengan hybrid tepung ubi jalar jenis lainnya. Hybrid tepung ubi jalar jenis orange $(\mathrm{O})$ memiliki nilai yang paling tinggi dibandingkan dengan hybrid tepung ubi jalar jenis lainnya. Kadar protein tepung ubi jalar orange pada penelitian Widyastuti; dkk (2015) sebesar 3,79\% tidak berbeda jauh dengan kadar protein hybrid tepung ubi jalar orange pada penelitian ini. Rendahnya kandungan protein hasil penelitian ini mungkin karena perbedaan varietas, umur panen ubi jalar dan lingkungan tumbuhnya.

Sudarmadji dkk. (1996) menyatakan bahwa protein mudah sekali mengalami perubahan yang dapat disebabkan oleh air dan panas. Dengan adanya perlakuan perendaman menggunakan larutan BAL 5\% serta pengeringan menggunakan cabinet dryer suhu $50^{\circ} \mathrm{C}$ selama $36 \mathrm{jam}$, diduga kadar protein pada berbagai jenis hybrid tepung ubi jalar sedikit mengalamin penurunan. Menurut Aruni; dkk (2014), selama perendaman akan terjadi penurunan protein yang disebabkan karena terlepasnya ikatan protein terlarut. Menurut Woolfe (1992), kandungan protein tertinggi pada ubi jalar terletak pada lapisan terluar daging umbi yang berdekatan dengan kulit luar. Adanya proses pengupasan yang berlebihan menyebabkan bagian daging ubi jalar yang kaya protein menjadi ikut terbuang.

Hasil uji lanjut DMRT menunjukkan bahwa terdapat perbedaan secara nyata kadar protein berbagai jenis hybrid tepung ubi jalar. Perbedaan kadar protein yang dihasilkan pada penelitian ini disebabkan karena perbedaan kadar protein awal berbagai jenis ubi jalar yang digunakan dalam penelitian, sehingga mempengaruhi kadar protein pada berbagai jenis hybrid tepung ubi jalar.

\section{Kadar Lemak}

Berdasarkan hasil penelitian, kadar lemak yang dihasilkan pada berbagai jenis hybrid tepung ubi jalar setelah mengalami perlakuan fermentasi dalam larutan Acetobacter xylinum konsentrasi 5\% berkisar antara 0,314-1,34\%. Beberapa hasil penelitian di Indonesia menunjukkan bahwa tepung ubi jalar yang dihasilkan memiliki kadar lemak rata-rata mencapai $0,75 \%$ dengan kisaran antara $0,50 \%$ $1,02 \%$. Hal ini menunjukkan bahwa kadar lemak dari berbagai jenis hybrid tepung ubi jalar yang diperoleh sesuai dengan kadar lemak dari beberapa hasil penelitian di Indonesia. Rendahnya kadar lemak merupakan ciri bagi tepung yang berasal dari umbi-umbian.

Hasil pengukuran kadar lemak menunjukkan bahwa hybrid tepung ubi jalar jenis ungu var. lokal (U) memiliki nilai yang paling rendah dibandingkan dengan hybrid tepung ubi jalar jenis lainnya. Hasil penelitian Julita (2012) menyatakan bahwa kadar lemak tepung ubi ungu var ayamurasaki sebesar $1,18 \%$. Hybrid tepung ubi jalar jenis orange (O) memiliki nilai yang paling tinggi dibandingkan dengan hybrid tepung ubi jalar jenis lainnya. Hasil penelitian Widyastuti, dkk (2015) menyatakan bahwa kadar lemak tepung ubi orange sebesar 1,33\% tidak berbeda jauh dengan kadar protein hybrid tepung ubi jalar orange pada penelitian ini. Menurut Susetyo dkk (2016), selama proses fermentasi berlangsung lemak tidak dengan mudah digunakan karena mikroba lebih cenderung memanfaatkan karbohidrat dan protein terlebih dahulu.

Hasil uji lanjut DMRT menunjukkan bahwa terdapat perbedaan secara nyata kadar lemak berbagai jenis hybrid tepung ubi jalar. Perbedaan kadar lemak yang dihasilkan pada penelitian ini disebabkan karena perbedaan kadar lemak awal berbagai jenis ubi jalar yang digunakan dalam penelitian, sehingga mempengaruhi kadar lemak pada berbagai jenis hybrid tepung ubi jalar.

\section{Kadar Serat}

Berdasarkan hasil penelitian, kadar serat yang dihasilkan pada berbagai jenis hybrid tepung ubi jalar setelah mengalami perlakuan fermentasi dalam larutan Acetobacter xylinum konsentrasi 5\% berkisar antara 2,613-8,399\%. Hasil pengukuran kadar serat menunjukkan bahwa hybrid tepung ubi jalar jenis cilembu (C) memiliki nilai yang paling rendah dibandingkan dengan hybrid tepung ubi jalar jenis lainnya. Beberapa hasil penelitian di Indonesia menunjukkan bahwa tepung ubi jalar yang dihasilkan memiliki kadar protein rata-rata mencapai 3,93\% dengan kisaran antara 1,95$5,54 \%$. Hal ini menunjukkan bahwa kadar serat dari berbagai jenis hybrid tepung ubi jalar yang diperoleh lebih tinggi dibandingkan dengan kadar serat dari beberapa hasil penelitian di Indonesia.

Hasil pengukuran kadar serat menunjukkan bahwa hybrid tepung ubi jalar jenis orange $(\mathrm{O})$ memiliki nilai yang paling tinggi dibandingkan dengan hybrid tepung ubi 
jalar jenis lainnya. Hasil penelitian Widyastuti, dkk (2015) menyatakan bahwa kadar serat tepung ubi orange sebesar $2,53 \%$ lebih rendah dibandingkan dengan kadar protein hybrid tepung ubi jalar orange pada penelitian ini. Hal ini sesuai dengan pernyataan Saxena et al. (1995), yang menyatakan bahwa perlakuan pemberian bakteri Acetobacter xylinum dalam proses pembuatan dengan menggunakan metode fermentasi memiliki kemampuan untuk mempolimerisasi glukosa sehingga mampu mengubah menjadi selulosa.

Kadar serat yang tinggi pada berbagai jenis hybrid tepung ubi jalar dapat meningkatkan nilai tambah produk, karena serat dalam makanan memiliki nilai positif bagi gizi dan metabolisme pada batas-batas yang masih bisa diterima oleh tubuh yaitu sebesar $100 \mathrm{mg} / \mathrm{kg}$ berat badan/hari (Ilminingtyas dan Kartikawati, 2009). Menurut Elisabeth dan Ambarsari (2009), kandungan serat tepung ubi jlar merupakan jenis serat larut yang memiliki kemampuan dalam menyerap kelebihan kadar lemak dan kolesterol dalam darah, serta sangat baik untuk mencegah gangguan percernaan dan kanker kolon.

Wibowo (2010), juga menyatakan bahwa kadar serat kasar dan kadar abu memiliki hubungan yang positif, tingginya serat kasar akan berpengaruh positif terhadap besarnya kadar abu pada suatu bahan. Hasil penelitian menunjukkan bahwa hybrid tepung ubi jalar jenis orange mengandung kadar abu dan kadar serat tertinggi dibandingkan dengan hybrid tepung ubi jalar lainnya. Dengan adanya kandungan serat kasar yang tinggi, maka dapat menjadikan tepung hybrid ubi jalar sebagai produk unggulan. Serat yang terdapat pada produk ini merupakan serat langsung dari bahan makanan (bukan serat suplemen).

Hasil uji lanjut DMRT menunjukkan bahwa terdapat perbedaan secara nyata kadar serat berbagai jenis hybrid tepung ubi jalar. Perbedaan kadar serat yang dihasilkan pada penelitian ini disebabkan karena perbedaan kadar serat awal berbagai jenis ubi jalar yang digunakan dalam penelitian, sehingga mempengaruhi kadar serat pada berbagai jenis hybrid tepung ubi jalar.

\section{Total Karbohidrat}

Berdasarkan hasil penelitian, total karbohidrat yang dihasilkan pada berbagai jenis hybrid tepung ubi jalar setelah mengalami perlakuan fermentasi dalam larutan Acetobacter xylinum konsentrasi 5\% berkisar antara 79,326$88,01 \%$. Beberapa hasil penelitian di Indonesia menunjukkan bahwa tepung ubi jalar yang dihasilkan memiliki total karbohidrat rata-rata mencapai 83,8\% dengan kisaran antara 81,74\%$85,26 \%$. Hal ini menunjukkan bahwa total karbohidrat dari berbagai jenis hybrid tepung ubi jalar yang diperoleh termasuk dalam kisaran total karbohidrat dari beberapa hasil penelitian di Indonesia.

Hasil pengukuran total karbohidrat menunjukkan bahwa hybrid tepung ubi jalar jenis orange $(\mathrm{O})$ memiliki nilai yang paling rendah dibandingkan dengan hybrid tepung ubi jalar jenis lainnya. Hybrid tepung ubi jalar ungu var. Antin 1 (PU) memiliki nilai yang paling tinggi dibandingkan dengan hybrid tepung ubi jalar jenis lainnya. Hal tersebut menunjukkan bahwa semakin turunnya karbohidrat akibat proses fermentasi maka kandungan protein akan semakin meningkat.

Hasil uji lanjut DMRT menunjukkan bahwa terdapat perbedaan secara nyata total karbohidrat berbagai jenis hybrid tepung ubi jalar. Perbedaan total karbohidrat yang dihasilkan pada penelitian ini disebabkan karena perbedaan total karbohidrat awal berbagai jenis ubi jalar yang digunakan dalam penelitian, sehingga mempengaruhi total karbohidrat pada berbagai jenis hybrid tepung ubi jalar.

\section{Aktivitas Antioksidan}

Berdasarkan hasil penelitian, aktivitas antioksidan yang dihasilkan pada berbagai jenis hybrid tepung ubi jalar setelah mengalami perlakuan fermentasi dalam larutan Acetobacter xylinum konsentrasi 5\% berkisar antara 29.383$53.7929 \%$.

Hasil pengukuran aktivitas antioksidan menunjukkan bahwa hybrid tepung ubi jalar jenis cilembu (C) memiliki nilai yang paling rendah dibandingkan dengan hybrid tepung ubi jalar jenis lainnya. Hybrid tepung Ubi ungu jepang var.Ayamurasaki (J) memiliki nilai yang paling tinggi $(53,7929 \%)$ dibandingkan dengan hybrid tepung ubi jalar jenis lainnya. Aktivitas antioksidan dominan dalam ubi jalar jepang disumbangkan oleh kandungan antosianin. Ubi jalar jepang mengandung antosianin dalam jumlah yang tinggi. Hal ini dikarenakan pada ubi jalar ungu jepang selain terdapat vitamin $\mathrm{A}$ dan $\mathrm{C}$, juga mengandung pigmen antosianin cukup tinggi berkisar antara $110 \mathrm{mg}-210 \mathrm{mg} / 100 \mathrm{gram}$ (Suprapta, 2003).

Antosianin yang merupakan pigmen warna ungu pada ubi jalar ini menyumbangkan antioksidan yang besar. ubi jalar ungu segar memiliki aktivitas antioksidan yang lebih tinggi 
$(61,07 \%)$ dari ubi jalar oranye $(8,38 \%)$ (Retnati, 2009). Sehingga saat diolah menjadi hybrid tepung ubi jalar, menghasilkan tepung dengan kandungan antioksidan yang lebih tinggi dari jenis lainnya. Menurut Nintami (2012), ubi ungu adalah bahan makanan sumber karbohidrat yang mengandung senyawa antosianin dan peonidin glikosida yang mempunyai aktivitas antioksidan lebih kuat. Berdasarkan data penelitian (Nintami, 2012), aktivitas antioksidan tepung ubi jalar ungu sebesar $36,88 \%$. Hybrid tepung ubi jalar ungu jenis lokal pada penelitian ini sebesar 43,327\%. Data menunjukkan bahwa hybrid tepung ubi jalar ungu pada penelitian ini lebih tinggi daripada hasil penelitian Nintami (2012). Hal ini disebabkan karena karbohidrat difermentasi oleh BAL yang menghasilkan senyawa fenolik yang menyebabkan aktivitas antioksidan semakin bertambah karena fenol adalah termasuk dari antioksidan (Rizky dan Elok, 2015).

Aktivitas antioksidan pada hybrid tepung ubi jalar pada penelitian ini tidak meningkat secara drastis. Hal ini diduga karena adanya perlakuan pengeringan hybrid tepung ubi jalar menggunakan kabinet dryer pada suhu $50^{\circ} \mathrm{C}$ selama 36 jam menyebabkan komponen asam menguap serta senyawa fenol yang terkandung di dalam ubi jalar banyak berkurang. Perlakuan fermentasi dalam larutan Acetobacter xylinum konsentrasi 5\% tanpa menginaktifkan enzim menyebabkan turunnya kemampuan senyawasenyawa yang berfungsi sebagai penangkap radikal bebas menyebabkan aktivitas antioksidan menjadi menurun. Selama perlakuan fermentasi terjadi proses hidrolisis yang dapat menyebabkan pemecahan ester atau glikosida dari antioksidan phenolic menjadi aglycones (Pokorny; et al. 2001). Untuk itu perlu dilakukan penelitian lebih lanjut mengenai proses pengolahan yang efektif sehingga dapat menginaktifkan enzim pada ubi jalar yang menyebabkan turunnya kemampuan senyawasenyawa yang berfungsi aktivitas antioksidan. Menurut Nintami (2012), aktivitas antioksidan berkurang akibat reaksi oksidasi ketika terkena udara $\mathrm{O}_{2}$ dan suhu pemanasan terlalu tinggi.

Hasil uji lanjut DMRT menunjukkan bahwa terdapat perbedaan secara nyata aktivitas antioksidan berbagai jenis hybrid tepung ubi jalar. Perbedaan aktivitas antioksidan yang dihasilkan pada penelitian ini disebabkan karena perbedaan komponen ubi jalar yang meliputi vitamin $\mathrm{A}, \mathrm{C}$, pigmen antosianin, dan $\beta$-karoten. yang berperan sebagai antioksidan awal berbagai jenis ubi jalar yang digunakan dalam penelitian, sehingga mempengaruhi aktivitas antioksidan pada berbagai jenis hybrid tepung ubi jalar.

\section{SIMPULAN}

Berdasarkan hasil penelitian dan pembahasan, maka disimpulkan bahwa terdapat perbedaan secara nyata terhadap kandungan gizi yang meliputi kadar air, kadar abu, kadar lemak, kadar protein, kadar serat serta total karbohidrat berbagai jenis hybrid tepung ubi jalar.

Aktivitas antioksidan yang dihasilkan pada berbagai jenis hybrid tepung ubi jalar setelah mengalami perlakuan fermentasi dalam larutan Acetobacter xylinum konsentrasi 5\% berkisar antara 29.383-53.7929\%. Nilai terendah didapat pada hybrid tepung ubi jalar cilembu dan nilai tertinggi didapat pada hybrid tepung ubi ungu jepang var.Ayamurasaki.

Aruni, Faza., Ira Dwitasari, dan Setiyo Gunawan. (2014). Pengaruh Waktu Fermentasi Menggunakan Lactobacillus Plantarum Terhadap Kandungan Protein Pada Tepung Mosof (Modified Sorghum Flour). Jurnal Teknik Pomits. Vol. 3, No. 2, (2014) Issn: 2337-3539.

Aulia, Rizki Eka dan Widya Dwi Rukmi Putri. (2015). Karakterisasi Sifat Fisikokimia Tepung Ubi Jalar Oranye Hasil Modifikasi Kimia dengan STPP. Jurnal Pangan dan Agroindustri, Vol. 3 No 2 P.476-482, April 2015. 
Bogasari. (2010). Seputar Tepung Terigu. www.bogasari.com. Diakses pada 02 Oktober 2017.

Elisabeth, D.A.A.,dan I. Ambarsari. (2009). Introduksi Teknologi Pengolahan Ubi Jalar Ungu menjadi berbagai produk olahan pangan di Kabupaten Gianyar, Bali. Prosiding Seminar Nasional Revitalisasi Pertanian dalam Menghadapi Krisis Ekonomi Global. Fakultas Pertanian, Universitas Sebelas Maret. Surakarta.

Ginting, E., Antarlina, S. S., Utomo, J. S., \& Ratnaningsih, R. (2006). Teknologi Pasca Panen Ubi Jalar Mendukung Diversifikasi Pangan Dan Pengembangan Agroindustri. Buletin Palawija, (11), 1528.

Ilminingtyas, D. dan D. Kartikawati, (2009). Potensi Buah Mangove Sebagai Alternatif Sumber Pangan. Universitas 17 Agustus, Semarang.

Julita, A.O. (2012). Karakteristik Tepung Pati dari Ubi Jalar Cilembu dan Ubi Jalar Ungu Ayuramurasaki. (Skripsi, Fakultas Teknologi Pertanian. Institut Pertanian Bogor). Bogor.

Muchtadi, D. (2001). Sayuran Sebagai Sumber Serat Pangan untuk Mencegah Timbulnya Penyakit Degeneratif. Jurnal Teknol. dan Industri Pangan, Vol. XII, No. 1 Th 2001.

Murtiningsih dan Suyanti. (2011). Membuat Tepung Umbi dan Variasi Olahannya. Jakarta: AgroMedia Pustaka.

Nintami, Ayudya Luthfia. (2012). Kadar Serat, Aktivitas Antioksidan, Amilosa dan Uji Kesukaan Mi Basah dengan Substitusi Tepung Ubi Jalar Ungu (Ipomea Batatas Var Ayamurasaki) Bagi Penderita Diabetes Mellitus Type 2. (Skripsi, Program Studi Ilmu Gizi Fakultas Kedokteran. UNDIP). Semarang.

Pokorny, J., N. Yanishleva, and M. Gordon. (2001). Antioxidant in Food. Woodhead Publishing Ltd. England.

Retnati. (2009). Pengaruh penambahan ekstrak berbagai jenis ubi jalar (Ipomoea batatas L) terhadap jumlah sel dan aktivitas antioksidan Yoghurt. (Skripsi, Fakultas pertanian Universitas Sebelas Maret). Surakarta.

Rizky, Anindita Mufti Dan Elok, Zubaidah. (2015). Pengaruh Penambahan Tepung Ubi Ungu Jepang (Ipomea Batatas L Var. Ayamurasaki) Terhadap Sifat Fisik, Kimia, Dan Organoleptik Kefir Ubi Ungu. Jurnal
Pangan Dan Agroindustri, Vol. 3 No 4 P.1393-1404, September 2015.

Saxena, I. M., Kudlicka, K., Okuda, K., \& Brown, R. M. J. R. (1995). Karakterisasi Gen di Sintesis Selulosa Operon (ACS Operon) dari Acetobacter xylinum: Implikasi untuk Kristalisasi Selulosa. Journal of Bacteriology, ay, 176.

Setiavani, Gusti. (2010). Kajian Pembuatan Tepung Cassava Modifikasi. (Karya Tulis Ilmiah, Polbangtan Medan). Medan. http://polbangtanmedan.ac.id/pdf/Jurnal\%2 0Vol\%205/5-Gusti.pdf

Sofyan, H.M.I. (2005). Pengaruh Suhu Inkubasi dan Konsentrasi Inokulum Rhizopus oligosporus terhadap Mutu Oncom Bungkil Kacang Tanah. Infomatek 5 (2). http://www.unpas.ac.id/pmb/home/images/art icles/infomatek/Jurnal_V_2-2.pdf. Diakses pada tanggal 02 Oktober 2017.

Subagio. A. (2008). Prosedur Operasi Standar (POS) Produksi Moccal Berbasis Klaster. Rusnas Diversifikasi Pangan Pokok. SEAFAST Center. IPB, Bogor.

Sudarmadji, I. B. (2003). Analisa Bahan Makanan dan Pertanian (Edisi ke 2 ed., Vol. III). Yogyakarta, DIY, Indonesia: Liberty Yogyakarta.

Sudarmadji. S., Haryono, B., Suhardi. (1996). Analisa Bahan Makanan dan Pertanian. Liberty Yogyakarta. Yogyakarta.

Suprapta. (2003). Pengaruh Lama Blanching terhadap Kualitas Stik Ubijalar (Ipomea batatas L.) dari Tiga Varietas. Prosiding Temu Teknis Nasional, Tenaga Fungsional Pertanian.

Suryati, L. (2014). Pengaruh Lama Pemanasan dalam Pemanas Berputar terhadap Penampakan Granula Pati, Kandungan Antosianin, Kapasitas Antioksidan dan Tingkat Hidrolisis Enzimatis Tepung Ubi Jalar Ungu Termodifikasi. (Tesis, Universitas Lampung). Bandar Lampung.

Susetyo, Yosia Adi., Sri Hartini dan Margareta Novian Cahyanti. (2016). Optimasi Kandungan Gizi Tepung Ubi jalar (Ipomoea batatas L.) Terfermentasi Ditinjau dari Dosis Penambahan Inokulum Angkak Serta Aplikasinya dalam Pembuatan Mie Basah. Jurnal Aplikasi Teknologi Pangan, Vol. 5 No.3

Wibowo, A. H. 2010. Pendugaan kandungan nutrient dedak padi berdasarkan karakteristik sifat fisik. (Tesis, Sekolah Pasca Sarjana, Fakultas peternakan. Institute Pertanian Bogor). Bogor. 
Widyastuti, Endrika., Ricca Claudia., Teti Estiasih dan Dian Widya Ningtyas. (2015). Karakteristik Biskuit Berbasis Tepung Ubi Jalar Oranye (Ipomoea Batatas L.), Tepung Jagung (Zea Mays) Fermentasi, dan Konsentrasi Kuning Telur. Jurnal
Teknologi Pertanian, Vol. 16 No. 1 [April 2015] 9-20.

Winarno, F. G. (1997). Kimia Pangan dan Gizi. Gramedia Pustaka Utama. Jakarta.

Woolfe, J.A. (1992). An Untapped Food Resource. Cambridge University Press, New York. 